\title{
Two Modes of 'Curing' Transmissible Bacterial Plasmids
}

\author{
By VYVYAN SALISBURY, R. W. HEDGES AND NAOMI DATTA \\ Department of Bacteriology, Royal Postgraduate Medical School, London, WI 2 oHS
}

\author{
(Accepted for publication 7 December 197I)
}

\begin{abstract}
SUMMARY
$\mathrm{F}^{\prime}$ lac was efficiently eliminated by acridine orange from Escherichia coli $\mathrm{KI} 2$, whether sex pilus synthesis was constitutive or repressed by an $f^{+} \mathbf{R}$ factor. $\mathbf{R}$ factors, F-like or I-like, repressed or derepressed, were not eliminated by acridine orange. Sodium dodecyl sulphate (SDS), known to eliminate certain plasmids determining constitutive synthesis of $F$ pili, had no effect on cultures with wild-type (repressed) $\mathrm{R}$ factors. Bacteria with derepressed synthesis of pili, either F-like or I-like, but particularly the latter, showed increased sensitivity to SDS. SDS treatment selected from such cultures non-piliated cells, with lost or mutant $\mathrm{R}$ factors. Thus acridine orange was a true 'curing' agent, specific for F, whilst SDS acted only by selection of spontaneous variants.
\end{abstract}

\section{INTRODUCTION}

Acridine dyes are very effective in curing Escherichia coli of the sex factor F (Hirota, I960). This plasmid produces sex pili constitutively. Acridines have little, if any, effect in elimination of R factors (Mitsuhashi, Harada \& Kameda, I96I; Watanabe \& Ogata, 1966). We have found that $\mathrm{F}$ factors can be eliminated equally efficiently from cells in which pili are produced constitutively and from those in which pilus production is repressed by the presence of an $f^{+} \mathrm{R}$ factor. Elimination of $\mathrm{F}$ factors by acridines seems to be due to a selective interference in the replication of the plasmid (Hohn \& Korn, I969; Yamagata \& Uchida, 1969) and is most clearly demonstrable in exponentially growing cultures (Hirota, I960). Thus curing by acridines normally involves loss of the whole plasmid.

We also show that mutants of F-like and I-like $\mathrm{R}$ factors with derepressed $(d r d)$ pilus synthesis are as little influenced by acridine orange as are the wild-type (pilus repressed) plasmids.

Tomoeda and co-workers (Tomoeda, Inuzuka, Kubo \& Nakamura, 1968; Inuzuka, Nakamura, Inuzuka \& Tomoeda, I969) showed that the detergent sodium dodecyl sulphate (SDS) was effective in eliminating F-lac and the R factor R IoodrdI. Both these plasmids produce F-like pili constitutively (Nishimura, Ishibashi, Meynell \& Hirota, 1967). We have investigated the effect of SDS on Escherichia coli $\mathrm{KI} 2$ carrying $\mathrm{R}$ factors, repressed or derepressed for the synthesis of F-like or I-like pili. Cultures of bacteria synthesizing pili constitutively were more sensitive to SDS than repressed cultures, in which pili are produced by only a minority of cells. Exposure to SDS led to selection of non-piliated cells; in some cases, but not all, the non-piliated cells had also lost resistance determinants.

\section{METHODS}

Bacteria. Escherichia coli $\mathrm{KI} 2$ strains, $\mathrm{J}_{53} \mathrm{~F}^{-}$pro met lac ${ }^{+}$and $\mathrm{J}_{2} \mathrm{~F}^{-}$pro his try lac ${ }^{-}$ (Clowes \& Hayes, 1968).

Media. Nutrient broth was Oxoid no. 2 (CM67). Nutrient agar was the same, solidified with $1 \cdot 2 \%$ New Zealand agar (Oxoid LI 3 ). Acridine orange broth was as described by 
Table I. Plasmids and phages used in these experiments

\begin{tabular}{|c|c|c|c|}
\hline \multirow{2}{*}{$\begin{array}{c}\text { Plasmids } \\
\text { F-like }\end{array}$} & & $\begin{array}{l}\text { Resistance } \\
\text { pattern }\end{array}$ & Reference \\
\hline & $\begin{array}{l}\mathrm{F}^{\prime} l a c \\
\mathrm{RI} \\
\mathrm{R} \mathrm{I} d r d \mathrm{I} 9 \\
\mathrm{R} I d r d \mathrm{I} 6 \\
\mathrm{R} I 92 \\
\mathrm{R} 192 d r d 7 \\
\mathrm{R} 538-\mathrm{I} \\
\mathrm{R} 53^{8}-\mathrm{I} d r d\end{array}$ & $\begin{array}{l}\text { ASCKSu } \\
\text { ASCKSu } \\
\text { K } \\
\text { SCTSu } \\
\text { SCTSu } \\
\text { SCSu } \\
\text { SCSu }\end{array}$ & $\begin{array}{l}\text { Jacob \& Adelberg, I959 } \\
\text { Lawn et al. 1967 } \\
\text { Lawn } \text { et al. 1967 } \\
\text { Frydman \& Meynell, } 1969 \\
\text { Lawn et al. } 1967 \\
\text { Lawn } \text { et al. } 1967 \\
\text { Romero \& Meynell, } 1969 \\
\text { Romero \& Meynell, } 1969\end{array}$ \\
\hline \multirow[t]{3}{*}{ I-like } & $\begin{array}{l}\text { RI44 } \\
\text { RI44drd3 } \\
\text { R64 } \\
\text { R64drd I I }\end{array}$ & $\begin{array}{l}\text { TK } \\
\text { TK } \\
\text { ST } \\
\text { ST }\end{array}$ & Lawn et al. 1967 \\
\hline & Phages & Receptor & \\
\hline & $\begin{array}{l}\text { MS2 } \\
\text { If I }\end{array}$ & $\begin{array}{l}\text { F pili } \\
\text { I pili }\end{array}$ & $\begin{array}{l}\text { Davis et al. 1961 } \\
\text { Meynell \& Lawn, } 1968\end{array}$ \\
\hline
\end{tabular}

Hirota (1960). MacConkey agar was Oxoid (CM7b). SDS was from Koch-Light Laboratories, Colnbrook, Buckinghamshire.

Plasmids and phages are listed in Table I.

Acridine orange $(A O)$ treatment. A small inoculum (200 to 500 bacteria) was added to acridine orange broth (Hirota, I960) with varying concentrations of acridine orange and incubated at $37^{\circ}$ overnight. Cultures containing the highest concentration of acridine orange in which growth was clearly visible were diluted and spread on MacConkey agar (when cultures contained $\mathrm{F}-\mathrm{lac} \mathrm{c}^{+}$) and nutrient agar plates. Where cultures contained $\mathrm{R}$ factors, colonies from the nutrient agar plates were replicated with velvet pads to nutrient agar plates incorporating appropriate antibiotic.

$S D S$ treatment. To $100 \mathrm{ml}$ of nutrient broth I $\mathrm{g}$ SDS was added. The solution was autoclaved, the $\mathrm{pH}$ adjusted to 7.6 and the solution steamed for $\mathrm{I} h$. Control broth without SDS was also adjusted to $\mathrm{pH} 7 \cdot 6$. Overnight stationary broth cultures were diluted I00-fold and $0.5 \mathrm{ml}$ added to each $100 \mathrm{ml}$ of broth. Cultures were incubated with aeration at $37^{\circ}$. Where SDS was required $8 \mathrm{~h}$ after bacterial inoculation a volume of sterile $10 \%(\mathrm{w} / \mathrm{v})$ SDS solution in nutrient broth $\mathrm{pH} 7 \cdot 6$ was added, sufficient to bring the concentration to $\mathrm{I} \%(\mathrm{w} / \mathrm{v})$. When chloramphenicol was added, $2.5 \mathrm{ml}$ of a solution containing $\mathrm{I} \mathrm{mg} / \mathrm{ml}$ was added to $100 \mathrm{ml}$ broth to give a final concentration of $25 \mu \mathrm{g} / \mathrm{ml}$. Viable counts were made after spreading O. I $\mathrm{ml}$ of dilutions of culture on nutrient agar plates and incubating at $37^{\circ}$. Extinction $(E)$ was measured at $675 \mathrm{~nm}$ with a spectrophotometer (Unicam SP600). Colonies from the viable count plates were tested for phage- and drug-sensitivity.

Testing for phage- and drug-sensitivity. Ditch plates containing appropriate concentrations of drug in nutrient agar ditches were used to test for drug resistance. Colonies were streaked across the ditches and also across streaks of phage (approximately ${ }^{1} 0^{10}$ particles per streak on $9 \mathrm{~cm}$ nutrient agar plates) to test for phage sensitivity. Phage- or drug-sensitive and phage- or drug-resistant cultures were streaked as controls on each plate. Visible lysis by phages MS2 or If I was our criterion for the constitutive production of F-like or I-like pili.

Matings. Procedure was as described by Datta et al. (1971). 
Table 2.

Acridine orange curing of $F^{\prime} l a c$ from cultures repressed and derepressed for pilus production

$\begin{array}{cccccc}\text { Culture } & \begin{array}{c}\text { Exposure } \\ \text { to acridine } \\ \text { orange }\end{array} & l a c^{+} \text {clones } & l a c^{-} \text {clones } & \text { Total } & \begin{array}{c}\text { Loss of } l a c^{+} \\ (\%)\end{array} \\ \mathrm{J} 62\left(\mathrm{~F}^{\prime} l a c^{+}\right) & - & 320 & 2 \mathrm{I} & 34 \mathrm{I} & 6 \cdot \mathrm{I} \\ & + & 52 & 372 & 424 & 88 \\ \mathrm{~J} 62\left(\mathrm{~F}^{\prime} l a c^{+}\right)(\mathrm{RI}) & - & 490 & 27 & 5 \mathrm{I} 7 & 5 \cdot 2 \\ & + & 4 & 324 & 328 & 99\end{array}$

Acridine orange curing of $\mathbf{R}$ factors from cultures repressed and derepressed for pilus production

\begin{tabular}{|c|c|c|c|c|c|}
\hline Culture & Exposure & $\begin{array}{l}\text { K-resistant } \\
\text { clones }\end{array}$ & $\begin{array}{l}\text { K-sensitive } \\
\text { clones }\end{array}$ & Total & $\begin{array}{c}\text { Loss of } \\
\mathbf{K} \text { resistance } \\
(\%)\end{array}$ \\
\hline $\mathrm{J} 62(\mathrm{RI})$ & $\overline{+}$ & $\begin{array}{r}1069 \\
499\end{array}$ & $\begin{array}{l}3 \\
0\end{array}$ & $\begin{array}{r}1072 \\
499\end{array}$ & $\begin{array}{l}<\mathrm{I} \\
<\mathrm{I}\end{array}$ \\
\hline $\mathrm{J} 62(\mathrm{R} 1 d r d \mathrm{I} 9)$ & $\overline{+}$ & $\begin{array}{r}1381 \\
554\end{array}$ & $\begin{array}{l}2 \\
0\end{array}$ & $\begin{array}{r}\text { I } 383 \\
554\end{array}$ & $\begin{array}{l}<\mathrm{I} \\
<\mathrm{I}\end{array}$ \\
\hline $\mathrm{J} 62\left(\mathrm{~F}^{\prime} l a c^{+}\right)(\mathrm{RI})$ & $\overline{+}$ & $\begin{array}{l}496 \\
402\end{array}$ & $\begin{array}{l}\text { I } \\
\text { I }\end{array}$ & $\begin{array}{l}497 \\
403\end{array}$ & $\begin{array}{l}<\mathrm{I} \\
<\mathrm{I}\end{array}$ \\
\hline J62(R I44) & $\overline{+}$ & $\begin{array}{l}682 \\
976\end{array}$ & $\begin{array}{l}4 \\
\mathrm{I}\end{array}$ & $\begin{array}{l}686 \\
977\end{array}$ & $\begin{array}{l}<\mathrm{I} \\
<\mathrm{I}\end{array}$ \\
\hline $\mathrm{J} 62\left(\mathrm{R} 144 d r d_{3}\right)$ & $\overline{+}$ & $\begin{array}{r}\mathrm{I} 288 \\
560\end{array}$ & $\begin{array}{l}3 \\
0\end{array}$ & $\begin{array}{r}129 \mathrm{I} \\
560\end{array}$ & $\begin{array}{l}<\mathrm{I} \\
<\mathrm{I}\end{array}$ \\
\hline
\end{tabular}

\section{Acridine orange treatment}

RESULTS

$\mathrm{F}^{\prime} l a c$ was eliminated with high efficiency from $\mathrm{J} 62\left(\mathrm{~F}^{\prime} l a c\right)$ and from $\mathrm{J} 62\left(\mathrm{~F}^{\prime} l a c\right)(\mathrm{RI})$ by $25 \mu \mathrm{g}$ acridine orange/ml. No elimination of $\mathrm{R}$ factors, F-like or I-like, repressed or derepressed for pilus synthesis, was observed (Table 2).

\section{SDS treatment}

(a) Control cultures. SDS had no effect on exponential growth of cultures without plasmids but in stationary phase the viable count fell and the extinction decreased disproportionately.

(b) F-like $R$ factors. Cultures with wild-type (repressed) $\mathrm{R}$ factors behaved like $\mathrm{R}^{-}$ controls. Cultures with the derepressed R factors, R IdrdI9 or R538-I $d r d$, were also unaffected by SDS during exponential phase; the decline in viable count and reduction in $E$ brought about by SDS during stationary phase were accelerated. The effect of SDS on J53(R538-I $d r d$ ) was less than on J53(RIdrdI9) (Fig. I).

SDS did not affect the properties of RI wild-type or RIdrdI9 during exponential phase. During stationary phase RI was still unaffected but the majority of surviving clones from the $\mathrm{J}_{53}(\mathrm{R} \mathrm{I} d r d \mathrm{I} 9)$ culture had lost phage sensitivity and all drug-resistance markers (Table 3 ). $\mathrm{R} 538$-I wild-type was completely stable throughout. R538-I $d r d$ was almost equally stable. No loss of phage sensitivity or drug resistance occurred in any clone tested up to $48 \mathrm{~h}$ incubation. At $72 \mathrm{~h}$ 10 \% of colonies from the SDS culture had lost all plasmid-determined characters.

The effect of SDS on cultures carrying R 192 and RI92drd7 was also tested. In one experiment, in which RI92drd7 was completely stable in the control, half of the surviving colonies from the SDS culture retained phage sensitivity and all three drug resistances, $20 \%$ had lost 

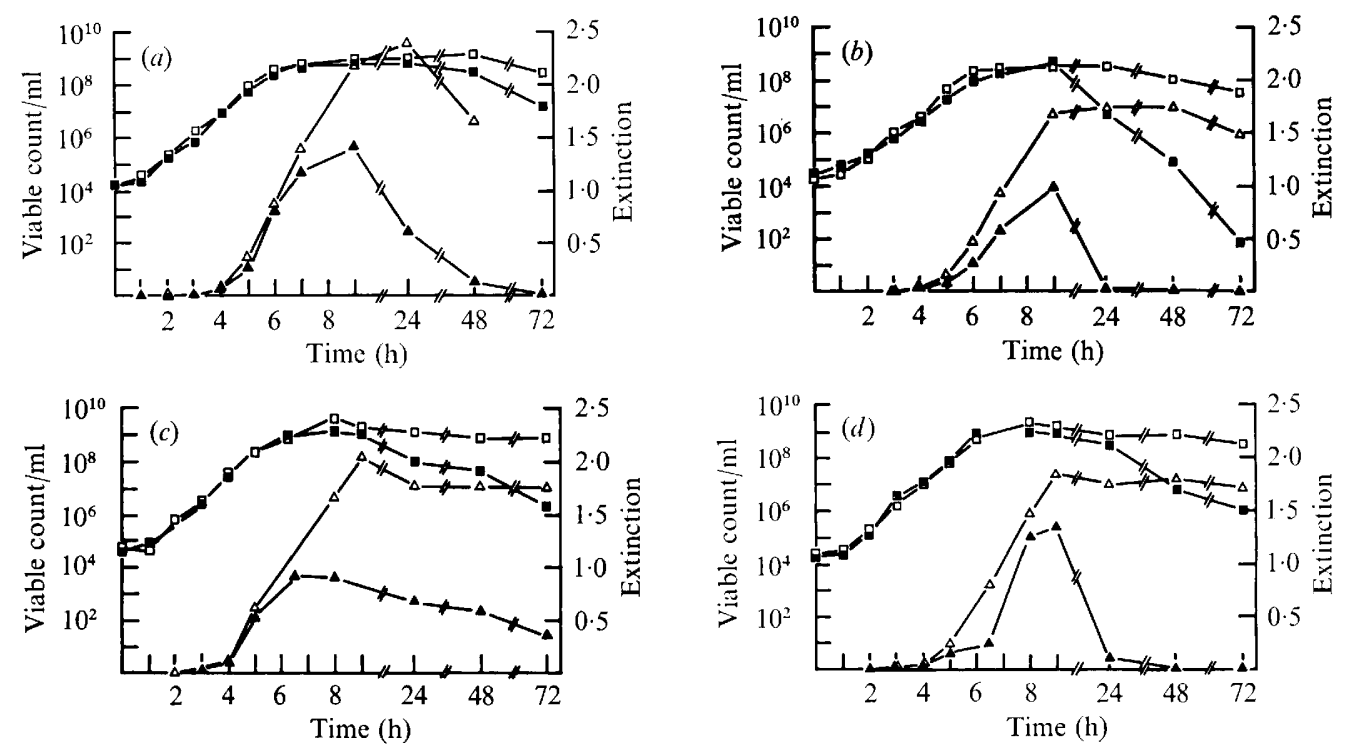

Fig. I. Effect of SDS on Escherichia coli carrying F-like R factors. (a) J53(RI); (b) J53(R I $d r d$ I9); (c) $\mathrm{J}_{53}\left(\mathrm{R}_{538}{ }^{-1}\right)$; $(d) \mathrm{J}_{53}(\mathrm{R} 538-\mathrm{I} d r d)$. $\square$, Viable counts, control; $\mathbf{\square}$, with SDS; $\triangle$, extinction, control; $\Delta$, with SDS.

Table 3. Plasmid determined properties of clones from cultures containing repressed and derepressed F-like $R$ factors, after growth with and without SDS

\begin{tabular}{|c|c|c|c|c|c|c|c|}
\hline \multirow[b]{3}{*}{ Culture } & \multirow{3}{*}{$\begin{array}{l}\text { Time of } \\
\text { sample }\end{array}$} & \multicolumn{3}{|c|}{+ SDS } & \multicolumn{3}{|c|}{ Control } \\
\hline & & Drug $^{r}$ & Drug $^{r}$ & Drug $^{8}$ & Drugr & Drug $^{r}$ & Drug \\
\hline & & $\mathrm{MS}_{2}^{\mathrm{g}}$ & $\mathrm{MS}^{\mathrm{r}}$ & $\mathrm{MS}_{2}^{\mathrm{r}}$ & $\mathrm{MS2}^{\mathrm{s}}$ & $\mathrm{MS}^{\mathrm{r}}$ & $\mathrm{MS}^{\mathrm{r}}$ \\
\hline \multirow[t]{7}{*}{$\mathrm{J} 53\left(\mathrm{RI}_{\mathrm{I}}\right)$} & 0 & - & $20 / 20$ & - & - & $20 / 20$ & - \\
\hline & 4 & - & $20 / 20$ & 一 & - & $20 / 20$ & - \\
\hline & 5 & - & $20 / 20$ & 一 & $\cdots$ & $20 / 20$ & 一 \\
\hline & 9 & - & $20 / 20$ & - & - & $20 / 20$ & - \\
\hline & 24 & - & $20 / 20$ & 一 & - & $20 / 20$ & - \\
\hline & 48 & - & $20 / 20$ & - & - & $20 / 20$ & - \\
\hline & 72 & - & $20 / 20$ & - & - & $20 / 20$ & - \\
\hline \multirow[t]{7}{*}{$\mathrm{J} 53(\mathrm{R} \mathrm{I} d r d \mathrm{I9})$} & o & $20 / 20$ & - & - & $20 / 20$ & - & - \\
\hline & 4 & $20 / 20$ & 一 & - & $20 / 20$ & 一 & - \\
\hline & 5 & $30 / 30$ & - & - & $20 / 20$ & - & - \\
\hline & 9 & $20 / 20$ & 一 & 一 & $20 / 20$ & - & - \\
\hline & 24 & $20 / 20$ & - & - & $20 / 20$ & - & - \\
\hline & 48 & $4 / 20$ & - & I $5 / 20$ & $20 / 20$ & - & - \\
\hline & 72 & $6 / 20$ & - & $14 / 20$ & $20 / 20$ & - & - \\
\hline \multirow[t]{6}{*}{$\mathrm{J}_{53}\left(\mathrm{R}_{53} 8-\mathrm{I}\right)$} & o & - & $20 / 20$ & - & - & $20 / 20$ & - \\
\hline & 5 & - & $20 / 20$ & - & - & $20 / 20$ & - \\
\hline & 9 & - & $20 / 20$ & - & 一 & $20 / 20$ & - \\
\hline & 24 & - & $20 / 20$ & - & - & $20 / 20$ & - \\
\hline & 48 & - & $20 / 20$ & - & - & $20 / 20$ & - \\
\hline & 72 & - & $20 / 20$ & - & - & $20 / 20$ & - \\
\hline \multirow{6}{*}{$\mathrm{J} 53(\mathrm{R} 538-\mathrm{I} d r d)$} & 0 & $20 / 20$ & - & - & $20 / 20$ & - & - \\
\hline & 5 & $20 / 20$ & - & - & $20 / 20$ & - & - \\
\hline & 9 & $20 / 20$ & - & - & $20 / 20$ & - & - \\
\hline & 24 & $20 / 20$ & - & - & $20 / 20$ & - & - \\
\hline & 48 & $20 / 20$ & - & - & $20 / 20$ & - & - \\
\hline & 72 & $18 / 20$ & - & $2 / 20$ & $20 / 20$ & - & - \\
\hline
\end{tabular}

Drug $^{r}=$ clones resistant to all antibiotics whose resistances are determined by the $\mathrm{R}$ factor. Drug $^{\mathrm{s}}=$ clones sensitive to all antibiotics whose resistances are determined by the $\mathrm{R}$ factor. 

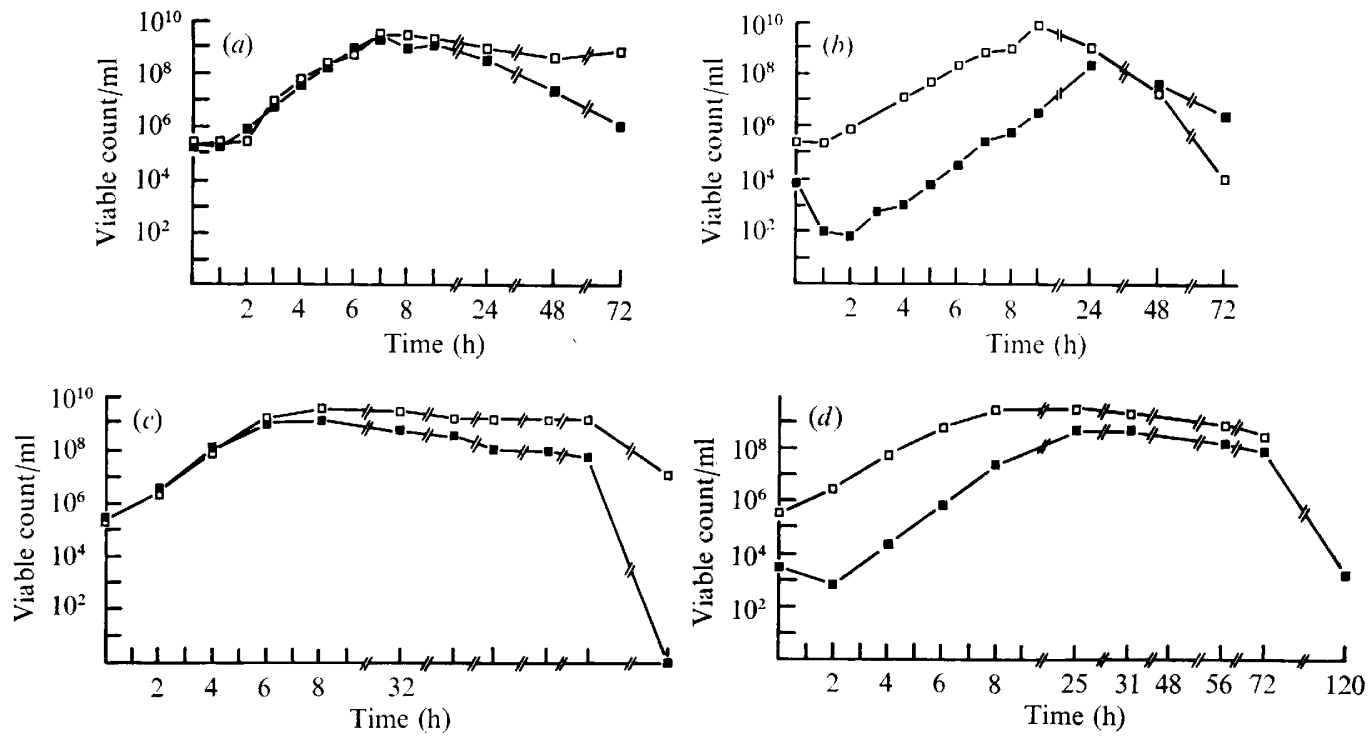

Fig. 2. Effect of SDS on Escherichia coli carrying I-like R factors. (a) J53(R64); (b) J53(R64drd I I); (c) $\mathrm{J} 53\left(\mathrm{R}_{144)}\right.$; (d) $\mathrm{J} 53\left(\mathrm{R}_{144 d r d 3}\right)$. Symbols as in Fig. I.

Table 4. Plasmid-determined properties of clones from cultures containing RI92drd7, after growth with and without SDS

\begin{tabular}{|c|c|c|c|c|c|c|c|}
\hline \multirow[b]{2}{*}{ Culture } & \multirow{2}{*}{$\begin{array}{l}\text { Time of } \\
\text { sample } \\
\text { (h) }\end{array}$} & \multicolumn{3}{|c|}{$+\mathrm{SDS}$} & \multicolumn{3}{|c|}{ Control } \\
\hline & & $\begin{array}{l}\text { STC }^{\mathbf{r}} \\
\text { MS }^{s}\end{array}$ & $\begin{array}{l}\text { STC }^{\mathbf{r}} \\
\text { MS }^{\mathbf{r}}\end{array}$ & $\begin{array}{l}\text { STC }^{\mathrm{g}} \\
{\text { MS } 2^{\mathrm{r}}}^{\mathrm{r}}\end{array}$ & $\begin{array}{l}\text { STC }^{r} \\
\text { MS }^{s}\end{array}$ & $\begin{array}{l}\mathbf{S T C}^{\mathrm{r}} \\
\mathrm{MS}_{2}{ }^{\mathrm{r}}\end{array}$ & $\begin{array}{l}\text { STC }^{\mathrm{s}} \\
\text { MS2 }^{2}\end{array}$ \\
\hline $153\left(\mathrm{RI}_{192} d r d 7\right)$ & 72 & $10 / 20$ & $4 / 20$ & $6 / 20$ & $20 / 20$ & - & - \\
\hline
\end{tabular}

phage sensitivity but retained drug resistance and $30 \%$ had lost all plasmid properties (Table 4). In other experiments, the tetracycline resistance and phage sensitivity of RI92drd7 were unstable in the control culture, although resistance to streptomycin, chloramphenicol and sulphonamide was retained. When this was so, the loss was accelerated by SDS, but resistance to streptomycin, chloramphenicol and sulphonamide remained stable.

(c) I-like $R$ factors. Wild-type I-like factors did not influence the growth or survival of their hosts in SDS medium. I-like factors with derepressed pilus production conferred marked sensitivity to SDS. Killing occurred as soon as detergent was added. Viable counts fell, but after $2 \mathrm{~h}$ rose at approximately the same rate as the control (Fig. 2). $\mathrm{J}_{53}(\mathrm{R} 64 d r d \mathrm{II}$ ) but not $\mathrm{J}_{53}\left(\mathrm{RI} 44 d r d_{3}\right)$ showed marked loss of viability in the control culture in stationary phase.

R64 was stable with and without SDS (Table 5). R64drdII in the control cultures was unaltered during the first $48 \mathrm{~h}$ but clones isolated after the population decrease mentioned above were phage-resistant (Table 5). The effect of SDS on plasmid-determined characters of ${ }_{53}(\mathrm{R} 64 d r d \mathrm{II})$ was early loss of phage sensitivity.

RI44 wild-type was unstable to the same extent in control and SDS cultures (Table 5). RI $44 d r d_{3}$ was stable in control cultures until well into stationary phase. After prolonged incubation phage-resistant mutants appeared. Two differences from the control were observed in the SDS cultures. Phage-resistant mutants appeared during log phase and many of the phage-sensitive clones (Table 5) were less clearly lysed than the parent J53(RI44drd3). 
Table 5. Plasmid-determined properties of clones from cultures containing repressed and derepressed I-like $R$ factors, after growth with and without $S D S$

\begin{tabular}{|c|c|c|c|c|c|c|c|}
\hline \multirow{2}{*}{ Culture } & \multirow[b]{2}{*}{$\begin{array}{l}\text { Time of } \\
\text { sample } \\
\text { (h) }\end{array}$} & \multicolumn{3}{|c|}{+ SDS } & \multicolumn{3}{|c|}{ Control } \\
\hline & & $\begin{array}{l}\text { Drug }^{\mathrm{r} *} \\
\text { If I }^{\mathrm{s}}\end{array}$ & $\begin{array}{l}\text { Drug } \\
\text { If }^{r}\end{array}$ & 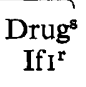 & $\begin{array}{c}\text { Drug }^{r} \\
\text { If I }^{8}\end{array}$ & $\begin{array}{l}\text { Drug } \\
\text { If }^{r}\end{array}$ & $\begin{array}{c}\text { Drug }^{s} \\
\text { If I }^{r}\end{array}$ \\
\hline \multirow[t]{7}{*}{ J53(R64) } & 0 & - & $20 / 20$ & 一 & - & $20 / 20$ & - \\
\hline & 4 & - & $20 / 20$ & $\longrightarrow$ & - & $20 / 20$ & - \\
\hline & 5 & - & $20 / 20$ & - & - & $20 / 20$ & - \\
\hline & 9 & - & $20 / 20$ & 一 & - & $15 / 15$ & - \\
\hline & 24 & - & $20 / 20$ & - & - & $20 / 20$ & - \\
\hline & 48 & - & $20 / 20$ & - & - & $20 / 20$ & - \\
\hline & 72 & - & $20 / 20$ & - & - & $20 / 20$ & 一 \\
\hline \multirow[t]{7}{*}{$\mathrm{J} 53(\mathrm{R} 64 d r d \mathrm{I} \mathrm{I})$} & 0 & $20 / 20$ & 一 & - & $20 / 20$ & - & - \\
\hline & 4 & $18 / 20$ & $2 / 20$ & - & $20 / 20$ & 一 & - \\
\hline & 5 & $15 / 20$ & $4 / 20$ & - & $20 / 20$ & 一 & 一 \\
\hline & 9 & $3 / 20$ & $17 / 20$ & - & 19/20† & - & - \\
\hline & 24 & - & $20 / 20$ & - & $20 / 20$ & 一 & - \\
\hline & 48 & - & $20 / 20$ & - & $10 / 10$ & - & - \\
\hline & 72 & - & $20 / 20$ & 一 & - & $20 / 20$ & $一$ \\
\hline \multirow[t]{10}{*}{ J53(RI44) } & 0 & - & $17 / 20$ & $3 / 20$ & - & - & - \\
\hline & 2 & - & $20 / 20$ & - & 一 & $17 / 20$ & $3 / 20$ \\
\hline & 4 & - & $17 / 20$ & $3 / 20$ & 一 & $19 / 20$ & $\mathrm{I} / 20$ \\
\hline & 6 & - & $18 / 20$ & $2 / 20$ & - & $17 / 20$ & $3 / 20$ \\
\hline & 8 & - & $15 / 20$ & $5 / 20$ & - & $18 / 20$ & $2 / 20$ \\
\hline & 25 & - & $17 / 20$ & $3 / 20$ & - & $16 / 20$ & $4 / 20$ \\
\hline & 3 I & - & $18 / 20$ & $2 / 20$ & $\omega$ & $20 / 20$ & - \\
\hline & 48 & - & I $8 / 20$ & $2 / 20$ & - & $18 / 20$ & $2 / 20$ \\
\hline & 56 & - & $17 / 20$ & $3 / 20$ & 一 & $17 / 20$ & $3 / 20$ \\
\hline & 72 & - & $17 / 20$ & $3 / 20$ & - & $17 / 20$ & $3 / 20$ \\
\hline \multirow[t]{9}{*}{$\mathrm{J} 53\left(\mathrm{RI}_{44 d r d 3}\right)$} & 0 & $7 / 8$ & $\mathrm{I} / 8$ & - & $20 / 20$ & - & - \\
\hline & 2 & $15 / 20$ & $5 / 20$ & - & $20 / 20$ & - & - \\
\hline & 4 & $15 / 207$ & $5 / 20$ & - & $20 / 20$ & 一 & - \\
\hline & 6 & $15 / 207$ & $5 / 20$ & - & $20 / 20$ & - & - \\
\hline & 8 & $14 / 20 \S$ & $6 / 20$ & - & $20 / 20$ & - & - \\
\hline & 25 & $12 / 20 \S$ & $8 / 20$ & - & $20 / 20$ & - & - \\
\hline & $3 I$ & $9 / 20 \S$ & II $/ 20$ & - & $20 / 20$ & - & - \\
\hline & 56 & $9 / 20 \$$ & I I $/ 20$ & - & $15 / 20$ & $5 / 20$ & - \\
\hline & 72 & $7 / 10 \$$ & $3 / 10$ & - & $2 / 10$ & $7 / 10$ & I/IO \\
\hline
\end{tabular}

* Clones resistant to all antibiotics whose resistances are determined by the $\mathrm{R}$ factor.

$\dagger$ The exceptional clone $(\mathrm{I} / 20)$ retained phage sensitivity and tetracycline resistance and had lost streptomycin resistance.

$\ddagger$ Many of these clones showed a lesser degree of If I lysis than the control.

$\S$ All these clones showed a lesser degree of If I lysis than the control.

\section{Transfer from phage-resistant variants}

From the SDS culture of $\mathrm{J}_{53}$ (RI92drd7), twenty phage-resistant mutant clones which had retained all drug-resistance markers were tested for ability to transfer drug resistance. Three of these gave no transfer (efficiency $<10^{-7}$ per donor), eight transferred at rates between $10^{-6}$ and $10^{-7}$ per donor, nine transferred at wild-type frequency, which was $10^{-2}$ per donor. J53(RI92drd7) control cultures transferred with an efficiency of I per donor cell.

Kinetics of the SDS effect

SDS affected $\mathrm{J}_{53}(\mathrm{RI} d r d \mathrm{I} 6)$ in the same way whether it was added at the beginning of exponential phase or the beginning of stationary phase (Fig. 3). The addition of chlor- 


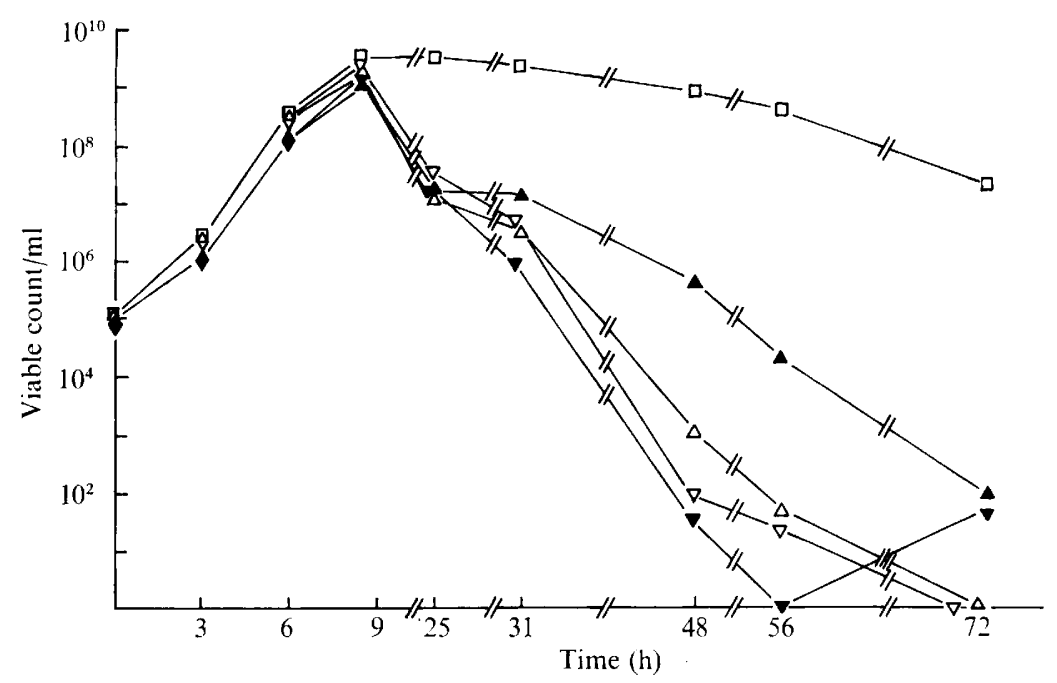

Fig. 3. Kinetics of SDS effect on Escherichia coli carrying an F-like R factor, with derepressed pilus synthesis. $\square, \mathrm{J} 53(\mathrm{RI} d r d \mathrm{I} 6)$ control; $\nabla$, SDS at $8 \mathrm{~h} ; \triangle$, SDS at $8 \mathrm{~h}$, chloramphenicol at $8 \mathrm{~h} ; \nabla$, SDS at $\circ \mathrm{h} ; \Delta, \operatorname{SDS}$ at o h, chloramphenicol at $8 \mathrm{~h}$.

amphenicol at the end of exponential phase had little effect on the viable count, but prevented the appearance of phage-resistant mutants in the SDS cultures (Table 6).

\section{DISCUSSION}

Acridine orange efficiently cured bacteria of $\mathrm{F}^{\prime} l a c^{+}$, whether $\mathrm{F}$ pili were being synthesized constitutively or not. No acridine orange curing of R factors, F-like or I-like, with repressed or derepressed pilus synthesis was demonstrated. Acridine orange, which probably intercalates into DNA, appears to have a specific effect on replication of the F factor (Hohn \& Korn, 1969; Yamagata \& Uchida, 1969). The results with SDS were quite different.

Presence of wild-type (pilus repressed) F-like or I-like plasmids had no demonstrable effect upon the response of the host to SDS. The presence of derepressed mutant plasmids had a marked, though variable effect, making their hosts more sensitive. Their increased sensitivity may result from the presence of pili on all cells in the culture. Detergents, including SDS, are known to act on the bacterial membrane (Tremblay, Daniels \& Schaechter, 1969) and sex pili may allow access of detergent to the membrane. This was suggested by Tomoeda et al. (1968), who postulated that the SDS might gain access to the membrane via the pili, that the plasmids are attached to membrane close to the pili and may thus be damaged. This implies a specific mutagenic action of the SDS on the plasmid. We consider it more probable that piliated cells themselves are especially susceptible to lysis by SDS and that the increase in the proportion of non-piliated cells is due, not to a direct effect on the plasmid, but to the selective advantage enjoyed by spontaneous non-piliated variants. Our results on the kinetics of the SDS effect (see Fig. 3 and Table 6) support this interpretation.

The presence of derepressed R-factors has other effects on the cell surface besides the constitutive synthesis of sex pili, for example that shown by a reduction in surface exclusion determined by the F factor (Willetts \& Finnegan, 1970). Dowman \& Meynell (I970) observed that the increased susceptibility to lysis by various agents, including SDS, conferred by derepressed I-like plasmids, was not due merely to the presence of sex pili. Dowman \& Meynell studied RI44drd3. We have consistently isolated clones from SDS cultures 
Table 6. Effect of SDS added at the beginning of log phase or in early stationary phase, with or without chloramphenicol in stationary phase on $\mathrm{J} 53(\mathrm{R} \mathrm{I} d r d \mathrm{I} 6)$

Twenty colonies were tested for each sampling where available.

\begin{tabular}{|c|c|c|c|c|c|}
\hline Treatment & $\begin{array}{l}\text { Time } \\
\text { (h) }\end{array}$ & $\mathbf{K}^{\mathbf{r}} \mathbf{M S}^{\mathrm{g}}$ & $\mathbf{K}^{\mathbf{r}} \mathbf{M S}^{\mathbf{r}}$ & $\mathrm{K}^{\mathrm{s}} \mathbf{M S}^{\mathrm{s}}$ & $\mathrm{K}^{\mathrm{s}} \mathrm{MS}^{\mathrm{r}}$ \\
\hline \multirow[t]{6}{*}{ Control } & $8 \frac{1}{2}$ & 20 & 0 & 0 & 0 \\
\hline & 24 & 20 & 0 & 0 & 0 \\
\hline & 32 & 20 & 0 & o & 0 \\
\hline & 49 & 20 & 0 & 0 & 0 \\
\hline & 57 & 20 & 0 & 0 & 0 \\
\hline & 72 & 20 & 0 & 0 & 0 \\
\hline \multirow[t]{5}{*}{ SDS o h } & $8 \frac{1}{2}$ & 19 & 0 & I & 0 \\
\hline & 24 & I9 & 0 & I & 0 \\
\hline & 32 & I4 & 6 & 0 & 0 \\
\hline & 49 & 0 & 0 & o & 6 \\
\hline & 72 & 0 & 10 & 0 & 0 \\
\hline \multirow{5}{*}{$\begin{array}{l}\text { SDS o h, } \\
\text { CHL } 8 \frac{1}{2} \mathrm{~h}\end{array}$} & $8 \frac{1}{2}$ & 20 & 0 & 0 & 0 \\
\hline & 24 & 20 & 0 & 0 & 0 \\
\hline & 32 & 20 & 0 & 0 & 0 \\
\hline & 49 & 20 & 0 & 0 & 0 \\
\hline & 72 & 13 & 0 & 0 & 0 \\
\hline \multirow{5}{*}{ SDS $8 \frac{1}{2} h$} & $8 \frac{1}{2}$ & 20 & 0 & 0 & 0 \\
\hline & 24 & 20 & 0 & 0 & 0 \\
\hline & 32 & 19 & 0 & 0 & I \\
\hline & 49 & 16 & 2 & 0 & 0 \\
\hline & 57 & o & 5 & 0 & 0 \\
\hline \multirow{5}{*}{$\begin{array}{l}\text { SDS } 8 \frac{1}{2} \mathrm{~h}, \\
\text { CHL } 8 \frac{1}{2} \mathrm{~h}\end{array}$} & $8 \frac{1}{2}$ & 20 & 0 & o & 0 \\
\hline & 24 & 20 & 0 & 0 & 0 \\
\hline & 32 & 20 & 0 & 0 & 0 \\
\hline & 49 & 17 & 0 & 0 & 3 \\
\hline & 57 & 10 & $\mathbf{I}$ & 0 & 0 \\
\hline
\end{tabular}

of $\mathrm{J}_{53}\left(\mathrm{R} \mathrm{R}_{44} d r d_{3}\right.$ ), whose sensitivity to phage If I was decreased (Table 5) although they were still visibly lysed. However, with many of the other derepressed R-factors studied, we obtained rather different results. Exposure to SDS led to selection of clones completely resistant to pilus specific phages. We believe therefore that non-susceptibility to SDS is strongly correlated with failure to produce pili. In one case, R $192 d r d 7$, we have investigated the nature of the phage-resistant mutants. Some seemed to be revertants to the repressed condition. Others were apparently point (revertible) mutants analogous to the tra mutants of $\mathrm{F}^{\prime}$ lac (Achtman, Willetts \& Clark, 197I).

Derepressed I-like and F-like factors had strikingly different effects on susceptibility of bacteria to SDS. During exponential phase growth in the presence of SDS, phage-resistant variants occurred in strains with derepressed I-like but not with derepressed F-like factors. Immediately on exposure to SDS there was a sharp fall in viability where the cells carried derepressed I-like factors. Resumption of growth, at normal rates, after this fall could not be explained exclusively as multiplication of pre-existing phage-resistant mutants (Fig. 2, Table 5). With cultures carrying derepressed F-like factors, phage-resistant clones were only detected in stationary phase. Where the derepressed F-like $\mathrm{R}$ factor markedly increased the lethal effect of SDS in the stationary phase, there was strong selection for phage-resistant variants for example, with $\mathrm{J} 53(\mathrm{R} I d r d \mathrm{I} 9)$. Where the $\mathrm{R}$ factor had less influence on viability, there was less selection for phage resistance, as with $\mathrm{J}_{53}(\mathrm{R} 538-\mathrm{I} d r d)$.

Phage-resistance, encountered in these experiments, was of two kinds - loss of phage 
sensitivity alone, or loss of all plasmid-determined characteristics, presumably loss of the whole plasmid. Each $\mathrm{R}$ factor tested tended to produce one or other of these variants on exposure to SDS. For example, RI $d r d \mathrm{I}$, an $i^{-} d r d$ mutant, according to the terminology of Frydman \& Meynell (1969), produced plasmidless variants but RIdrdI6, an $o^{c}$ mutant (Frydman \& Meynell, 1969; but see Willetts \& Finnegan, I97I) of the same R factor, RI, produced exclusively drug-resistant, phage-resistant variants (i.e. retained the plasmid). This may reflect the reversion rates of the two $d r d$ mutants of RI. Both derepressed I-like factors lost phage resistance whilst retaining drug-resistance markers.

In cultures carrying $\mathrm{F}$-like derepressed $\mathrm{R}$ factors the increase of phage-resistant mutants occurred in the stationary phase. The action of SDS, manifested in stationary phase, was actually exerted in this phase (Fig. 3). This could be due either to a direct effect of SDS on nondividing bacteria or to a replacement by turnover of phage-sensitive types by resistant variants. Treatment of the SDS stationary phase cultures with the bacteriostatic antibiotic, chloramphenicol, prevented the emergence of phage-resistant mutants (Fig. 3, Table 6). The simplest interpretation of these results is that the antibiotic prevented multiplication of phage-resistant mutants. Thus, according to the definition of Novick (1969), the effect of SDS on $d r d \mathrm{R}$ factor carrying cultures is not true curing but rather a selection of plasmidless clones or of clones carrying mutant plasmids.

V.S. was supported by an M.R.C. Scholarship for Training in Research Methods during the course of this work.

\section{REFERENCES}

Achtman, M., Willetts, N. \& Clark, A.J.(197I). Beginning of a genetic analysis of conjugational transfer determined by the $\mathrm{F}$ factor in Escherichia coli by isolation and characterization of transfer deficient mutants. Journal of Bacteriology 106, 529-536.

Clowes, R. C. \& HAYES, W. (1968). Experiments in Microbial Genetics. Oxford: Blackwell Scientific Publications.

Datta, N., Hedges, R. W., Shaw, E., Sykes, R. B. \& Richmond, M. H. (i97i). Properties of an R factor from Pseudomonas aeruginosa. Journal of Bacteriology Io8, I 244-1249.

Davis, J. E., Strauss, J. H. \& Sinsheimer, R. L. (196I). Bacteriophage MS 2: another RNA phage. Science, New York 134, 1427.

Dowman, J. E. \& Meynell, G. G. (1970). Pleiotropic effects of derepressed bacterial sex factors on colicinogeny and cell wall structure. Molecular and General Genetics 109, 57-68.

Finnegan, D. J. \& Willetts, N. S. (197I). Two classes of $F^{\prime}$-lac mutants insensitive to transfer inhibition by an F-like R factor. Molecular and General Genetics III, 256-264.

Frydman, A. \& MeYNell, E. (I969). Interactions between derepressed F-like R factors and wild-type colicin B factors: superinfection immunity and repressor susceptibility. Genetical Research $\mathbf{1 4}, 31$ 5-322.

Hirota, Y. (1960). The effect of acridine dyes on mating type factors in Escherichia coli. Proceedings of the National Academy of Sciences of the United States of America 46, 57-64.

Hohn, B. \& KorN, D. (1969). Co-segregation of a sex factor with the Escherichia coli chromosome during curing by acridine orange. Journal of Molecular Biology 45, 385-395.

Inuzuka, N., Nakamura, S., Inuzuka, M. \& Tomoeda, M. (1969). Specific action of sodium dodecyl sulphate on the sex factor of Escherichia coli $\mathrm{K} 2 \mathbf{2} \mathrm{Hfr}$ strains. Journal of Bacteriology roo, 827-835.

JACOB, F. \& ADELBERG, E. A. (I959). Transfert de charactères génétiques par incorporation au facteur sexuel d'Escherichia coli. Comptes rendues des séances de l'Académie des sciences 249, I 89-19I.

Lawn, A. M., Meynell, G. G. \& Datta, N. (1967). Sex pili and the classification of sex factors in the Enterobacteriaceae. Nature, London 216, 343-346.

Meynell, G. G. \& Lawn, A. M. (1968). Filamentous phages specific for the I sex factor. Nature, London 2I7, I I 84-I I 86.

Mitsuhashi, S., HARAdA, K. \& KAMEDA, M. (196I). Elimination of transmissible drug resistance by treatment with acriflavin. Nature, London 139, 947. 
Nishimura, Y., Ishibashi, M., Meynell, E. \& Hirota, Y. (1967). Specific piliation directed by a fertility factor and a resistance factor of Escherichia coli. Journal of General Microbiology 49, 89-98.

Novick, R. P. (1969). Extrachromosomal inheritance in bacteria. Bacteriological Reviews 33, 210-263.

Romero, E. \& MeYNell, E. (1969). Covert $f^{-}$R factors in $f^{+}$strains of bacteria. Journal of Bacteriology 97, $780-786$.

Tomoeda, M., InuzuKa, M., Kubo, N. \& Nakamura, S. (1968). Effective elimination of drug resistance and sex factors in Escherichia coli by sodium dodecyl sulphate. Journal of Bacteriology 95, 1078-1089.

Trembilay, G. Y., Daniels, M. J. \& Schaechter, M. (I969). Isolation of a cell membrane-DNA ${ }^{+}$nascent RNA' complex from bacteria. Journal of Molecular Biology 40, 65-76.

WATANABE, T. \& OGATA, C. (1966). Episome-mediated transfer of drug resistance in Enterobacteriaceae. IX. Recombination of an R factor with F. Journal of Bacteriology 9r, 43-50.

WilletTS, N. S. \& FINNEGAN, D. J. (1970). Characteristics of E. coli K I 2 strains carrying both an F prime and an R factor. Genetical Research 16, II 3-132.

YAMAGATA, H. \& UCHIDA, H. (I969). Effect of acridine orange on sex factor multiplication in Escherichia coli. Journal of Molecular Biology 46, 73-84. 